\title{
IMPLEMENTASI MANAJEMEN SUMBER DAYA MANUSIA DI PONDOK PESANTREN
}

\author{
ITTIHAD*

\section{STIT PALAPA NUSANTARA LOMBOK NTB}

Email: ittihadkalijaga@gmail.com

\begin{abstract}
Abstrak. Fokus pada penelitian ini disaat banyak lemabaga pendidikan mengalami penurunan peserta didik yang signifikan, justru Pondok Pesantren Syaikh Zainuddin NW Anjani mengalami kenaikan santri. Dalam membekali masa depan santri, Ponpes Syaikh Zainuddin NW Anjani memberikan pelajaran agama, umum dan keterampilan. Penelitian tentang manajemen sumber daya manusia merupakan penelitian lapangan menggunakan pendekatan kualitatif. Kehadiran peneliti di lapangan sebagai instrumen. penelitian di lakukan di Pondok Pesantren Syaikh Zainuddin NW Anjani. Data yang digunakan dalam penelitian ini berupa data tuli yang bersumber dari dua macam yaitu: informan dan arsip (dokumen). Teknik pengumpulan data melalui wawancara (interview). Pengamatan (Obesrvasi) dan dokumentasi. Teknik analisis data kualitatif dilakukan secara interaktif dan berlangsung secara terus menerus sampai tuntas, sehingga datanya sudah jenuh. Menyatakan hasil penelitian bahwa karakteristik Pondok Pesantren Syaikh Zainuddin NW Anjani menurut tipenya termasuk dalam pondok pesantren modernt yakni pondok pesantren kalafi, menurut tipe Pondok Pesantren tipe D. Implementasi manajemen sumber daya manusia pondok pesantren Syaikh Zainuddin NW Anjani dilakukan sebagai berikut: perencanaan dilakukan berdasarkan analisis trend, selanjutnya dirumuskan dalam bentuk perencanaan, pengorganisasian selanjutnya dilakukan pembagian tugas pengurus dan tenaga pendidik. Pelaksanaan meliputi: metode rekrutmen belum terbuka sehingga tidak ada seleksi. Orientasi belum dilaksanakan pada semua tenaga baru. Pelatihan untuk materi umum masih tergantung panggilan dari Kanwil Kemenag Kabupaten Lombok Timur. Pengendalian meliputi:penilaian baru menggunakan cara pendekatan individual. Kompensasi yang diberikan tidak sesuai dengan job analisis.
\end{abstract}

Kata-kata Kunci: Implementasi, Pondok Pesantren, Manajemen Sumber Daya manusia 


\section{PENDAHULUAN}

Pondok pesantren Syaikh Zainuddin NW Anjani merupakan bentuk pendidikan yang menyeimbangkan antara pendidikan keagamaan dan pendidikan umum. Kelebihannya pondok pesantren Syaikh Zainuddin NW Anjani memberikan suatu penyegaran dalam pembentukan sistem pendidikan yang sudah modernisasi. Tujuan proses modernisasi dalam tubuh pesantren adalah untuk menyempurnakan sistem pendidikan islam yang ada dalam pesantren.

Keterpaduan pondok pesantren Syaikh Zainuddin NW Anjani antara ilmu pengetahuan keagamaan islam dengan ilmu pengetahuan umum dan teknologi, merupakan langkah pesiapan lemnaga pendidikan ini untuk mempersiapkan peserta didiknya atau santrinya untuk memasuki era globalisasi yang penuh persaingan dalam berbagai dimensi kehidupan. Fenomena tersebut perlu diungkapkan secara empiris, sehingga dapat diakses dan sekaligus lebih memberikan motivasi dalam rangka percepatan pencapaian tujuan dan peningkatan kualitas lembaga secara komperehensif.

Dalam pelaksanaan modernisasi ditubuh pondok pesantren Syaikh Zainuddin NW Anjani diperlukan kerjasama dari semua stakeholder untuk menjamin kelancarannya. Salah satu upaya lah manajemen sumber daya manusia yang meliputi: perencanaan meliputi Job analisis dan perencanaan, pengorganisasian, pelaksanaan meliputi rekrutmen, seleksi, orientasi, pelatihan dan pengendalian meliputi penilaian dan kompensasi, sebagai usaha untuk memberdayakan sumber daya manusia dalam rangka pencapaian tujuannnya menghasilkan output yang baik yaitu santri yang berkualitas sebagai calon intelektual muslim yang handal. Untuk mengupas masalah ini perlu diungkap halhal sebagai berikut:

Pondok pesantren merupakan tempat belajar dan tempat tinggal para santri yang dibimbing oleh seorang kyai yang disini juga berfungsi sebagai pimpinan dan para ustad dalam rangka memperdalam ilmu agama islam secara mendalam dan komprehensip. Berdasarkan jenisnya sebuah pondok pesantren dapat di bedakan menjadi 5 jenis: 
Menurut jenisnya pondok pesantren dibedakan menjadi lima yaitu: pertama, pondok pesantren yang paling sederhana. Disini masjid digunakan sebagai tempat pengajaran agama Islam. Jenis ini khas bagi pesantren sufi dengan pengajian yang teratur dalam masjid dengan pengajaran pribadi oleh kyai kepada anggota kaum; Kedua, bentuk dasar dilengkapi dengan suatu pondok yang terpisah, asrama bagi para santri yang sekaligus menjadi ruangan untuk tinggal dan belajar yang sederhana. Jenis ini mempunyai semua komponen pesantren klasik; Ketiga, pesantren itu dengan komponen-komponen klasik yang telah diperluas dengan suatu madrasah. Kurikulum madrasah berorientasi pada sekolahsekolah pemerintah resmi; Keempat, selain perluasan komponen pesantren klasik dengan suatu madrasah, juga mempunyai tambahan program pendidikan ketrampilan dan terapan bagi santri maupun remaja desa sekitarnya. Seperti program pertanian, pertukangan, peternakan, menjahit, dan sebagainya; Kelima, pesantren modern yang disamping sektor pendidikan ke-Islaman klasik, juga mencakup semua tingkat sekolah umum dari tingkat dasar sampai pendidikan tinggi. Parallel dengan itu diselenggarakan pendidikan ketrampilan ${ }^{1}$

Sedangkan pada umumnya pondok pesantren dapat dikelompokan menjadi dua macam, yaitu: 1) pesantren salafi, yang mengkhususkan mengajarkan agama hanya dengan menggunakan kitab klasik sebagai inti pendidikan, dan 2) pesantren kalafi, yaitu pondok pesantren yang selain mengajarkan kitab-kitab klasik yang harus dipelajari juga memasukkan pelajaran umum sebagai inti pendidikan serta menggunakan sistem pendidikan persekolahan ${ }^{2}$

Berdasarkan Keputusan Mentri Agama Republik Indonesia No. 3/1997, ada empat tipe pondok pesantren, yaitu:pertama, pesantren tipe A, yaitu pesantren dimana para santri belajar dan bertempat tinggal bersama guru (kyai). Kurikulum terserah pada kyai, cara memberikan pelajaran individual dan tidak menyediakan madrasah untuk belajar.lahan (madrasah) dalam pengajarannya; Kedua pesantren tipe B, yaitu pesantren yang memiliki madrasah dan kurikulum pengajarannya dari kyai dilakukan dengan cara stadium jeneral, pengajaran poko terletak pada

${ }^{1}$ Ziemek, Manfred, Pesantren dalam Perubahan Sosial. (Jakarta: LP3M. 1986), h. 40

${ }^{2}$ Dhofier, Zamakhsyari, Tradisi Pesantren, Study Tentang Pandangan Hidup Kyai. (Jakarta:LP3S. 1994), h. 30 
madrasah yang diselenggarakan. Kyai memberikan pelajaran secara umum kepada para santri pada waktu yang telah ditentukan. Para santri tinggal di lingkungan itu dan mengikuti pelajaran dari kyai disamping mendapatkan ilmu pengetahuan agama dan umum di madrasah; Ketiga, pesantren tipe $\mathrm{C}$, yaitu pesantren yang fungsinya utamanya hanya sebagai tempat tinggal atau asrma, santrinya belajar di madrasah atau di sekolah sekolah umum, fungsi kyai sebagai pengawas, Pembina mental dan pengajar agama; Keempat, pesantren tipe D, yaitu pesantren yang menyelenggarakan sistem pondok dan sekaligus sistem sekolah atau madrasah.

Manajemen adalah merupakan proses merencanakan, mengorganisasikan, memimpin, dan mengendalikan organisasi agar tujuan organisasi dapat tercapai.

Manajemen sumber daya manuasia, dapat diaikan sebagai pengelolaan individu-individu yang bekerja dalam organisasi berupa hubungan antar pekerja dengan pekerja, terutama untuk menciptakan dan memanfaatkan individu-individu secara produktif sebagai usaha mencapai tujuan organisasi dan dalam rangka perwujudan kepuasan kerja dan pemenuhan kebutuhan-individu tersebut.

Proses manajemen sumber daya manusia kegiatan manajemen sumber daya manusia secara menyeluruh terdiri dari : analisis pekerjaan perencanaan SDM. Rekrutmen dan seleksi. Orientasi, pelatihan dan pengembangan, perencanaan karier, kompensasi penilaian kerja, hubungan kerja termasuk disiplin kerja dan penyelesaian konflik serta motivasi kerja

Analisis pekerjaan adalah proses pengumpulan informasi mengenai suatu pekerjaan yang dilakukan oleh seorang pekerja yang dilaksanakan dengan cara mengamati terhdap pekerja yang dilaksanakan dengan cara mengamati terhadap pekerja, dari bukti-bukti yang benar dari supervisor. ${ }^{3}$ Perencanaan Sumber Daya Manusia mendifinisikan perencanaan adalah kegiatan yang akan dilakukan di masa yang akan dating untuk mencapaitujuan; ${ }^{4}$ Pengorganisasian adalah proses mendesain kegiatan kegiatan dalam struktur organisasi untuk mencapai tujuan yang telah ditetapkan. ${ }^{5}$ 91.

\footnotetext{
${ }^{3}$ Gomes, Faustino, Manajemen Sumber Daya Manusia. (Yogyakarta: CV.Andi, 2003) h.
}

${ }^{4}$ Husaini Usman, Manajemen. (Yogyakarta: Edisi 3, Bumi Aksara. 2009). h. 6

${ }^{5}$ Husaini Usman, Manajemen. (Yogyakarta: Edisi 3, Bumi Aksara. 2009.) h.146 
Pengorganisasian sumber daya manusia adalah proses mendesain kegiatan kegiatan dalam struktur organisasi untuk mencapai tujuan yang telah ditetapkan. ${ }^{6}$ Rekrutmen dan seleksi adalah suatu proses pencarian dan pemikatan para calon tenaga kerja (karyawan) yang mempunyai kemampuan sesuai dengan rencana kebutuhan organisasi. ${ }^{7}$ Orientasi dan penempatan harapan masing masing Pelatihan adalah teknik belajar yang melibatkan pengamatan individual pada pekerjaan dan penentuan umpan balik untuk memperbaiki kinerja atau mengoreksi kesalahan; Penilaian Kinerja atau prestasi kerja adalah proses evaluasi atau untuk unjuk kerja pegawai yang dilakukan oleh organisasi. ${ }^{8}$ Kompensasi (sistem/skala upah/gaji) adalah segala sesuatu yang diterima oleh karyawan sebagai balas jasa untuk kerja atau pengabdian. ${ }^{9}$

\section{METODE}

Penelitian tentang manajemen sumber daya manusia merupakan penelitian lapangan menggunakan pendekatan kualitatif. Kehadiran peneliti di lapangan sebagai instrumen. penelitian di lakukan di Pondok Pesantren Syaikh Zainuddin NW Anjani. Data yang digunakan dalam penelitian ini berupa data tuli yang bersumber dari dua macam yaitu: informan dan arsip (dokumen). Teknik pengumpulan data melalui wawancara (interview). Pengamatan (Obesrvasi) dan dokumentasi. Teknik analisis data menyatakan bahwa aktivitas dalam analisis data kualitatif dilakukan secara interaktif dan berlangsung secara terus menerus sampai tuntas, sehingga datanya sudah jenuh. ${ }^{10}$

\footnotetext{
${ }^{6}$ Husaini Usman, Manajemen. (Yogyakarta: Edisi 3, Bumi Aksara. 2006.) h.146

${ }^{7}$ Notoatmojo, Soekijo . Pengembangan Sumber Daya Manusia. (Jakarta: Rineka Cipta. 2009) h. 105.

${ }^{8}$ Danim, Sudarwan. Kinerja Staf Dan Organisasi, Perspektif Pendidikan, Pelatihan, Pengembangan, Dan Kewidyaiswaraan Berbasis kinerja. (Bandung:CV. Pustaka Setia.2008) h. 43

${ }^{9}$ Notoatmojo, Soekijo . Pengembangan Sumber Daya Manusia. (Jakarta: Rineka Cipta. 2009) h. 142.

10 Sugiyono, 2010. Metode Penelitian Pendidikan. (Edisi ke 10. Bandung: Alfabeta. 2010) h. 337)
} 


\section{HASIL DAN PEMBAHASAN}

Karaktestik Pondok Pesantren Syaikh Zainuddin Syainuddin NW Anjani berada di Desa Anjani Kecamatan Suralaga kabupaten Lombok Timur, menurut jenis pondok pesantren ini termasuk pondok pesantren moderent yaitu pesantren yang disamping sektor pendidikan keislaman klasik, juga mencakup semua tingkat sekolah umum dari tingkat SDI sampai pendidikan tinggi. Paralel dengan itu diselenggarakan pendidikan keterampilan yaitu menjahit, cetak dan perikanan.

Menurut kelompok pondok pesantren Syaikh zainuddin NW Anjani termasuk pesantren kalafi yaitu pondok pesantren yang selaain mengajarkan kitab-kitb klasik yang harus dipelajari, juga memasukkan pelajaran umum sebagai inti pendidikan serta menggunakan sistem pendidikan persekolahan (madrasah) dalam pengajarnnya. Menurut tipe pondok pesantren ini Syaikh Zainuddin NW Anjani termasuk tipe D yaitu pesantren yang menyelenggarakan sistem pondok sekaligus sistem sekolah.

Perencanaan Sumber Daya Manusia di pondok pesantren Syaikh zainuddin NW Anjani. Job analisis dan perencanaan. Perencanaan yang dilakukan menggunakan analisis trend yaitu data tahun lampau digunakan untuk memprediksi kebutuhan sumber daya manusia di masa mendatang. Analisis ini memang cukup mudah dan bagus, tetapi ada kelemahannya, yaitu: bahwa tingkat kebutuhan sumber daya manusia tidak sepenuhnya tergantung pada data historis, ada faktor-faktor lain seperti perubahan jumlah pendaftaran anak dengan lulusan, yang juga akan mempengaruhi kebutuhan sumber daya manusia di masa mendatang.

Pengorganisasian sumber daya manusia, sistem pengorganisasian yang dilakukan perlu adanya pengembangan yang cukup signifikan, karena jika diamati pengorganisasian di pondok pesantren Syaikh Zainuddin NW Anjani baru pada bagian organisasi sebagai struktur (desain organisasi) yang diantaranya adalah pembagian tugas.

Oleh karena organisasi merupakan alat untuk mencapai tujuan organisasi, maka pada bagian organizing dalam MSDM harus benar-benar melengkapi sesuai dengan teori yang ada. Dengan organizing yang baik berarti alat untuk mencapai 
tujuan baik sehingga tujuanny untuk mencetak santri yang berkualitas akan mudah tercapai.

Pelaksanaan Manajemen Sumber Daya Manusia. Hasil penelitian dapat dikatan bahwa sudah melaksanakan rekrutmen dengan baik, yaitu membagi tahapan-tahapan menjadi empat (identifikasi tenaga pendidik, sumber calon, metode rekrutmen, penawaran lowongan). Sehingga jumlah pendidik sudah sesuai dengan jumlah murid yang ada dengan kualifikasi yang tepat dan sesuai job.

Jika dianalisis pelaksanaan seleksi di pondok pesantren Syaikh Zainuddin NW Anjani cukup sederhana tetapi hasilnya dapat maksimal, di buktikan dari data yang ada bahwa pengajarnya semua berpendidikan S1 dan kebanyakan sudah mempunyai jabatan penting diinstansi negara maupun swasta, dalam hal ini yang agak sulit adalah menganalisis tenaga sekitar yang berkompeten dan merayu bagaimana orang yang dituju mau dan bahkan tertarik untuk ikut memperjuangkan pendidikan di pondok pesantren Syaikh zainuddin NW Anjani. Data penelitian dapat disimpulkan bahwa bahwa ponpes Syaikh zainuddin NW Anjani sudah melaksanakan orientasi, walaupun dengan metode sederhana dan biaya yang relatif tujuan orientasi dapat tercapai.

Pelatihan yang dilaksanakan ponpes sudah ada dan sesuai dengan tujuan tetapi tidak ada salahnya jika pengurus pondok mengetahui langkah langkah penyelenggaraan pelatihan dan pengembangan, agar pelatihan menjadi lebih fokus sesuai dengan kebutuhan pondok pesantren. ${ }^{11}$

Penilaian yang dilakukan pengurus Pondok Pesantren Syaikh Zainuddin NW Anjani relatif sederhana dan perlu dikembangkan dimana penilaian kinerja harus: 1) menetapkan standar kerja; 2) menilai prestasi kerja pegawai secara nyata dibandingkan dengan standar kerja yang telah ditetapkan; 3) memberikan umpan balik kepada pegawai dengan tujuanuntuk memotivasi pegawai agar meningalkan prestasi yang buruk dan mempertahankan, bahkan meningkatkan prestasi yang sudah baik.

${ }^{11}$ Sirait, 2006, Memahami Aspek-aspek Pengelolaan Sumber Daya Manusia dalam Organisasi. (Jakarta: PT Gramedia. 2006) h. 14. 


\section{Simpulan}

Hasil penelitian dan pembahasan dapat disimpulkan pertama, karakteristik pondok pesantren Syaikh Zainuddin NW Anjani adalah 1) menurut jenisnya termaasuk pondok pesantren modern yaitu pesantren yang disamping sektor pendidikan keislaman klasik, juga mencakup semua tingkat sekolah umum dari tingkat dasar sampai pendidikan tinggi. Paralel dengan itu diselenggaraka pendidikan keterampilan; 2) Menurut kelompok pondok pesantren Syaikh zainuddin NW Anjani termasuk pesantren kalafi yaitu pondok pesantren yang selaain mengajarkan kitab-kitb klasik yang harus dipelajari, juga memasukkan pelajaran umum sebagai inti pendidikan serta menggunakan sistem pendidikan persekolahan (madrasah) dalam pengajarnnya; 3) Menurut tipe pondok pesantren ini Syaikh Zainuddin NW Anjani termasuk tipe D yaitu pesantren yang menyelenggarakan sistem pondok sekaligus sistem sekolah.

Kedua, implementasi manajemen sumber daya manusia pondok pesantren Syaikh zainuddin NW Anjani sebagai berikut: 1) Perencanaan yang dilakukan menggunakan analisis trend, selanjutnya dirumuskan dalam bentuk perencanaan; 2) pengorganisasian baru dilakukan pembagian tugas pengurus dan tenaga pendidik; 3) pelaksanaan meliputi metode rekrutmen belum terbuka sehingga seleksi kurang maksimal, pelaksanaan orientasi tenaga pendidik baru belum merata, pelatihan untuk materi umum masih tergantung panggilan dari Kanwil; 4) Pengendalian meliputi: penilaian baru menggunakan cara pendekatan individual dan kompensasi yang diberikan tidak sesuai dengan job analisis.

\section{DAFTAR PUSTAKA}

Danim, Sudarwan, 2008. Kinerja Staf Dan Organisasi, Perspektif Pendidikan, Pelatihan, Pengembangan, Dan Kewidyaiswaraan Berbasis kinerja. Bandung:CV. Pustaka Setia.

Dhofier, Zamakhsyari, 1994. Tradisi Pesantren, Study Tentang Pandangan Hidup Kyai. Jakarta:LP3S.

Gomes, Faustino, 2003. Manajemen Sumber Daya Manusia. Yogyakarta: CV.Andi.

Husaini Usman, 2009. Manajemen. Yogyakarta: Edisi 3, Bumi Aksara. 
Notoatmojo, Soekijo , 2009. Pengembangan Sumber Daya Manusia. Jakarta: Rineka Cipta.

Rohiat, 2010. Manajemen Sekolah. Bandung: Refika Aditama.

Sugiyono, 2010. Metode Penelitian Pendidikan. Edisi ke 10. Bandung: Alfabeta.

Sirait, 2006, Memahami Aspek-aspek Pengelolaan Sumber Daya Manusia dalam Organisasi. Jakarta: PT Gramedia.

Ziemek, Manfred, 1986. Pesantren dalam Perubahan Sosial. Jakarta: LP3M. 